\title{
Erratum to: New technologies. Political, legal, economic and factual impact in Germany
}

\section{German National Report. World Congress of the International Insurance Law Association (AIDA) 2018}

\section{Christian Armbrüster}

Published online: 6 July 2020

(C) Springer-Verlag GmbH Deutschland, ein Teil von Springer Nature 2020

\section{Erratum to:}

\section{ZVersWiss 2020}

https://doi.org/10.1007/s12297-020-00460-2

Dear readers,

The article New technologies. Political, legal, economic and factual impact in Germany, written by Christian Armbrüster, was originally published electronically on the publisher's internet portal on May, 19th, 2020 without open access. With the author decision to opt for Open Choice the copyright of the article changed on July 2020 to $\odot$ The Author(s) 2020 and the article is forthwith distributed under a Creative Commons Attribution 4.0 International License (https://creativecommons. org/licenses/by/4.0/), which permits use, sharing, adaptation, distribution and reproduction in any medium or format, as long as you give appropriate credit to the original author(s) and the source, provide a link to the Creative Commons licence, and indicate if changes were made.

"The original version of this article was NOT revised due to a retrospective Open Access order".

The online version of the original article can be found under https://doi.org/10.1007/s12297-02000460-2. 